\title{
Article
}

Doi 10.5943/sif/3/1/5

Copyright $(\odot$ Institute of Animal Science, Chinese Academy of Agricultural Sciences

\section{First record of Mayamontana coccolobae (Stephanosporaceae: Agaricales) from Mexico}

\author{
de la Fuente $\mathbf{J I}^{1}$, Guevara-Guerrero $\mathbf{G}^{\mathbf{1}}$, López $\mathrm{CY}^{\mathbf{2}}$ and García-Jiménez $\mathbf{J}^{\mathbf{1}}$ \\ ${ }^{1}$ Instituto Tecnológico de Ciudad Victoria. Blv. Emilio Portes Gil \#1301Pte. CP87010, Cd Victoria, Tamaulipas, \\ México \\ ${ }^{2}$ Instituto Tecnológico de Chetumal. Av. Insurgentes \# 330, Col. David G. Gutiérrez, C P 77013, Chetumal, Q. Roo, \\ México.
}

de la Fuente JI, Guevara-Guerrero G, López CY, García-Jiménez J 2018 - First record of Mayamontana coccolobae (Stephanosporaceae: Agaricales) from Mexico. Studies in Fungi 3(1), 34-38, Doi 10.5943/sif/3/1/5

\begin{abstract}
Mayamontana coccolobae Castellano, Trappe and Lodge is described for the first time from Mexico and the second time worldwide. It is characterized by the orange, subhypogeous basidiomata and the wrinkled subglobose spores with conspicuous hilar appendix. It is not a very common species in the region and is recorded from disturbed lowland forest and urban gardens. Mayamontana coccolobae was only known from the type locality but now extends its geographical distribution to southeast Mexico.
\end{abstract}

Key words - Macrofungi - Truffles - Truffle-like Fungi - Yucatán Peninsula

\section{Introduction}

Stephanosporaceae Oberw and E Horak includes hypogeous and resupinated fungi, distinguished by ornamented spores with a crown-like structure composed by pyramidal spines (Vidal 2004). Stephanosporaceae currently comprises 8 genera and 37 species all over the world (Kirk et al. 2008). Despite its worldwide distribution, it is poorly known in Mexico where is only represented by one single species: Stephanospora michoacanensis Guevara and Castellano (Guevara et al. 2015).

Mayamontana coccolobae Castellano, Trappe and Lodge was described from the mayan mountains in Belize growing under Coccoloba belizensis Stand and Neea sp. This species is characterized by a bright orange peridium and spores with conspicuous hilar appendage, absent in other sequestrated taxa (Castellano et al. 2007). Although M. coccolobae lacks ornamented spores, recent molecular evidences place $M$. coccolobae within the Stephanosporaceae, closely related to Stephanospora Pat and the resupinated fungi Lindtneria trachyspora Bourdot and Galzin Pilát (Lebel et al. 2015).

During mycological explorations in southern Campeche and Quintana Roo in the years 2015 and 2017 in the Yucatán peninsula, several hypogeus fungi with orange peridium where collected under Byrsonima crassifolia (L.), Coccoloba diversifolia Jacq, Coccoloba spicata Lundell, Gymnopodium floribundum Rolfe and Haematoxylum campechianum L. The morphological and microscopical features match well with those from $M$. coccolobae and it represents the first record from Mexico and the second record worldwide. 


\section{Materials \& Methods}

Basidiomata were collected at Calakmul municipality in Campeche state and urban gardens from Chetumal city in Quintana Roo state, Mexico. The vegetation is a disturbed lowland forest with Coccoloba diversifolia Jacq, Metopium brownei (Jacq.) Urb, Haematoxillon campechianum, Gymnopodium floribundum Rolfe and Acoelorraphe wrightii (Griseb. \& H. Wendl.) H. Wendl. ex Becc. (Valdéz \& Islebe 2011) and urban gardens with $C$. spicata and B. crassifolia. The traditional collecting, sampling and describing methods for sequestrated fungi were used (Castellano et al. 2004). Hand cuts sections were made in dried specimens mounted in $\mathrm{KOH} \mathrm{5 \% ,} \mathrm{Congo} \mathrm{Red} \mathrm{and}$ Lugol for microscopic description. The hand book of color (Kornerup \& Wanscher 1978) was used for the color terminology. All the specimens were herborized and deposited at mycological herbarium "José Castillo Tovar" of Instituto Tecnológico de Ciudad Victoria (Index Herbarium ITCV).

\section{Results}

Six M. coccolobae fruiting bodies were collected at Calakmul municipality in Campeche state and urban gardens in Chetumal city in southern Quintana Roo state, Mexico. A taxonomic description, discussion, distribution and photographies of the species are provided.

Mayamontana coccolobae Castellano, Trappe \& Lodge.

Figs 1-4

Basidiomata subhypogeus, scattered, 11-16 mm, globose to subglobose, without rhizomorphs or columella. Peridum cadmium orange (5A8) to deep or bright orange (6A8), rugulose to wrinkled, wet, dehiscent, sometimes showing the locules inside. Gleba brittle, pale orange to yellowish (5B5) with rounded to slightly elongate locules reaching $1 \mathrm{~mm}$, odor and taste slightly fungoid.

Peridium 94-126 $\mu \mathrm{m}$ wide, with subparallel, interwoven, globose and inflated hyphae 5.5-16 $\mu \mathrm{m}$ diam, hyaline, orange or bright yellow in $\mathrm{KOH} 5 \%$, thin-walled or with irregular walls, without clamp connections. Hymenophoral trama 39-50 $\mu \mathrm{m}$ wide, with inflated hyphae 4.2-14.3 $\mu \mathrm{m}$, hyaline or bright orange in $\mathrm{KOH}$, thin-walled. Basidia clavate to subclavate, $20-26 \times 9-11 \mu \mathrm{m}$, hyaline, 2-spored to 4-spored, thin-walled, collapsing after spore development. Basidiospores broadly ellipsoid to ovoid, 7.8-11.4 × 6.4-8.4 $\mu \mathrm{m}(\mathrm{L}=9.573, \mathrm{~W}=9.475, \mathrm{Q}=1.009, \mathrm{~N}=30)$, with conspicuous hilar appendix reaching $3 \mu \mathrm{m}$ long, sometimes flattened in one side, hyaline or pale green in $\mathrm{KOH} 5 \%$, slightly wrinkled, thin-walled.

Known distribution - known from the Mayan mountains in Belize, Southern Quintana Roo and Campeche State, Mexico.

Examined material - Mexico: Quintana Roo state, Othón P. Blanco municipality, Chetumal city, urban gardens of the Instituto Tecnológico de Chetumal, under B. crassifolia and C. spicata. September 19 2015, (18³1'11.65" N, 88¹8'19.54" W), de la Fuente 95 (ITCV). Campeche state, Calakmul municipality, Blasillo, under G. floribundum and H. campechianum, December 102017 $\left(18^{\circ} 09^{\prime} 42.22^{\prime \prime} \mathrm{N}, 88^{\circ} 13^{\prime} 42.22^{\prime \prime} \mathrm{W}\right)$ de la Fuente 380 (ITCV).

Notes - Morphological characters of Mexican collections are very similar to those quoted by Castellano et al. (2007) except the basidiomata size, being the Mexican material bigger (6-8 mm vs 11-16 mm). Mayamontana coccolobae has been reported in association with $C$. belizencis and Neea sp. The Mexican specimens were found growing under C. spicata, C.diversifolia, $G$. floribundum and $H$. campechianum always in disturbed vegetation. Rinaldi et al. (2008) consider $M$. coccolobae as an ectomycorrhizal fungus but according to recent molecular data from Tedersoo et al. (2010) there is no evidence that $M$. coccolobae forms a mycorrhizal association despite growing under ectomycorrhizal host trees.

The weather and vegetation of southern Mexico is very similar to that of Belize (Durán et al. 2000) and according to our field observations, is very possible that M. coccolobae expands his current distribution to all along the Yucatan peninsula (Fig. 5). It is important to remark that all the specimens were found in disturbed vegetation, urban gardens and near paths in the forest and despite more mycological exploration were conducted in well stablished forest no basidiomata were 
found, this could indicate a preference of $M$. coccolobae for disturbed vegetation or secondary forest.

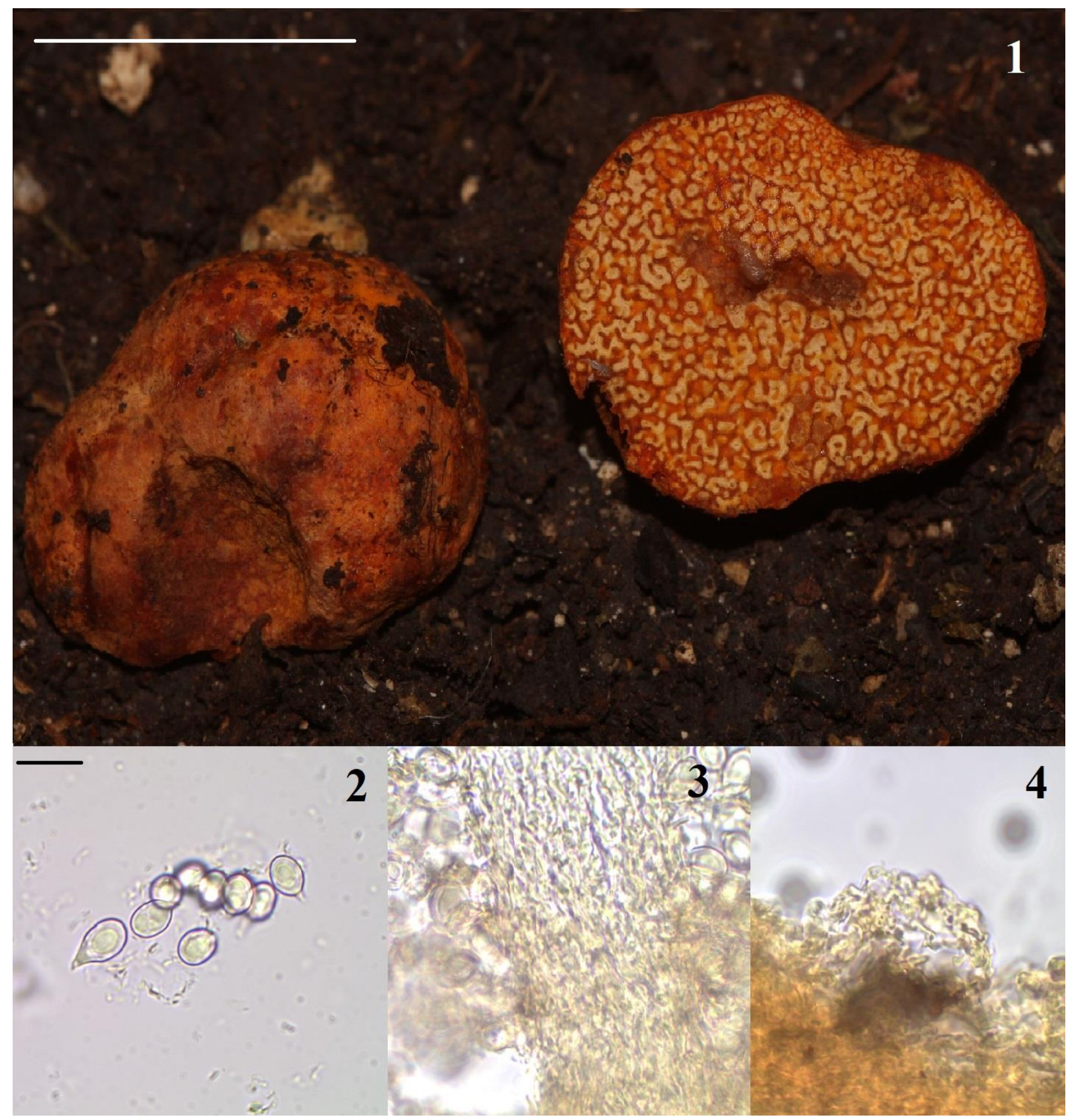

Figs 1-4 - Mayamontana coccolobae. 1 Basidiomata and Gleba. 2 Basidiospores. 3 Trama. 4 Peridium cells (Bar: 1, $1 \mathrm{~cm} ; 2,10 \mu \mathrm{m}$ ). 


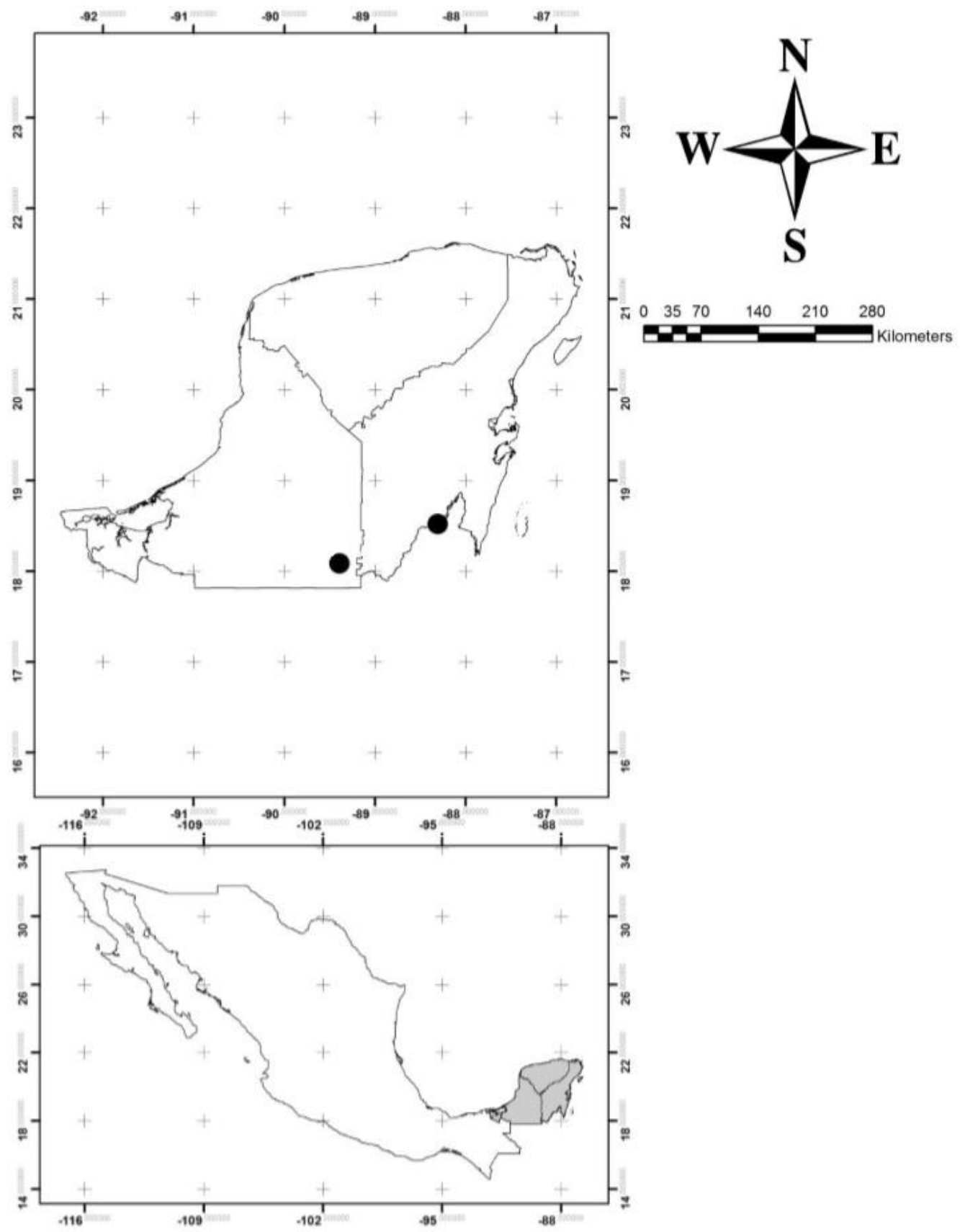

Fig. 5 - Current distribution of Mayamontana coccolobae in Mexico.

\section{Acknowledgements}

de la Fuente thanks CONACYT for financial support and León Ibarra, Israel Mota, David Ávila, Sergio Ibarra and Alan Canúl for field and technical support. García-Jiménez and GuevaraGuerrero thank PRODEP, CONACYT and Instituto Tecnológico de Ciudad Victoria for financial support.

\section{References}

Castellano MA, Trappe JM, Lodge DJ. 2007 - Mayamontana coccolobae (Basidiomycota), a new sequestrate taxon from Belize. Mycotaxon 100, 289-294. 
Castellano MA, Trappe JM, Luoma DL. 2004. Sequestrated fungi. In: Muller G, Bills G, Foster M. (eds.) Biodiversity of fungi Inventory and monitoring methods. Elseviere academic press, California. pp 197-213.

Durán R, Campos G, Trejo JC, Cimá P, May-Pat F, Juan-Qui M. 2000 - Listado florístico de la Península de Yucatán. CICY, Mérida.

Guevara-Guerrero G, Báez-Alvarado I, Gómez-Reyes V, Castellano MA. 2015 - Stephanospora michoacanensis (Stephanosporaceae, Agaricales), a novel sequestrate truffle from North America. Revista Mexicana de Micología 41, 73-77.

Kirk PM, Canon PF, Minter DW, Stalpers JA. 2008 - Ainsworth and Bisby Dictionary of the Fungi. CABI, Wallingford.

Kornerup A, Wanscher H. 1978 - Methuen handbook of color. Eyre, London.

Lebel T, Castellano, MA, Beever RE. 2015 - Cryptic diversity in the sequestrate genus Stephanospora (Stephanosporaceae: Agaricales) in Australasia. Fungal biology 119, 201228.

Rinaldi AC, Comandini O, Kuyper TW. 2008 - Ectomycorrhizal fungal diversity: separating the wheat from the chaff. Fungal diversity 33, 1-45.

Tedersoo L, May TW, Smith ME. 2010 - Ectomycorrhizal lifestyle in fungi: global diversity, distribution, and evolution of phylogenetic lineages. Mycorrhiza 20: 217-263.

Valdéz M, Islebe G. 2011. Tipos de vegetación en Quintana Roo. In: Pozo C, Armijo C, Calmé NS. (eds.) Riqueza biológica de Quintana Roo. Gobierno del Estado de Quintana Roo, Chetumal. pp 32-75.

Vidal J. 2004 - The genus Stephanospora Pat., Two new combinations. Revista catalana de micología 26, 97-111. 